\title{
Annual variation of phytoplankton communities and its driving environmental factors in a subtropical mussel-fish integrated pond in China
}

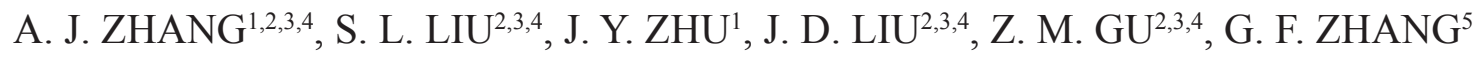 \\ AND K. H. LU ${ }^{1}$ \\ ${ }^{1}$ Key Laboratory of Applied Marine Biotechnology, Ministry of Education, School of Marine Sciences, Ningbo \\ University, Ningbo - 315 211, P. R. China \\ ${ }^{2}$ Zhejiang Institute of Freshwater Fisheries, Huzhou - 313 001, P. R. China \\ ${ }^{3}$ Key Laboratory of Healthy Freshwater Aquaculture, Ministry of Agriculture, Huzhou - 313 001, P. R. China \\ ${ }^{4}$ Key Laboratory of Freshwater Aquatic Animal Genetic and Breeding of Zhejiang province \\ Huzhou - 313 001, P. R. China \\ ${ }^{5}$ JinHua Polytechnic College, JinHua - 321 000, P. R. China \\ e-mail:lukaihong@nbu.edu.cn
}

\begin{abstract}
In this study, phytoplankton communities as well as environmental factors in a subtropical mussel-fish integrated pond in China were investigated during December 2012 to November 2013. Phytoplankton showed distinct seasonal density shifts in community structure at both taxonomic and functional levels. Cryptophyta was the dominant assemblage in low and moderate temperature, especially in January, April and May. Cryptophyta was gradually replaced by Cyanophyta with increase in temperature and formed cyanobacterial bloom in July. Chlorophyta became the most dominant group in the following six months with the second dominant assemblages of Cyanophyta, Cryptophyta and Bacillariophyta every two months in turn. Bacillariophyta was the dominant assemblage in March with low temperature and nutrients concentration. It appeared that water temperature and total nitrogen $(\mathrm{TN})$ were the most critical factors driving phytoplankton community shift in terms of density and biomass, respectively.
\end{abstract}

Keywords: Cyanobacterial bloom, Phytoplankton community, Temperature, Temporal variation

\section{Introduction}

Phytoplankton being the main primary producers, form an important component in aquatic ecosystems and play major role in energy flow and matter cycling (Finlay et al., 1998). Phytoplankters are also used as bioindicators in water quality monitoring owing to their rapid growth rates and as they quickly respond to environmental changes than other aquatic organisms ( $\mathrm{Xu}$ et al., 2008). Therefore, understanding the characteristics and processes in spatial and temporal dynamics of phytoplankton communities in aquaculture ponds is crucial for effective and sustainable management. Temporal changes in phytoplankton communities usually depend on temporal variations of ambient physical factors, nutrient concentrations and biotic factors (Sommer et al., 1986). Relationships between them have rapidly gained increasing attention in natural and artificial water bodies (Tucker et al., 1984; Xu et al., 2008; Lv et al., 2014; Masmoudi et al., 2015).

The triangle sail mussel Hyriopsis cumingii (Lea, 1852) is the most important mussel species in commercial freshwater pearl production of China, which is exported to many countries since 1970 s. In traditional farming ponds, H. cumingii is co-cultured with planktivorous fishes (Hypophthalmichthys molitrix and Aristichthys nobilis) and excessive organic manure is used for providing natural food (phytoplankton and detritus) for the mussels and fishes, consequently resulting in serious environmental problems. Previous studies found that introducing selected omnivorous or herbivorous fish species (Ctenopharyngodon idella and Carassius auratus) in the traditional mussel-fish integrated system and feeding the fishes with formulated feed with less or even no manure in pond could significantly improve the quality of aquatic environment and reduce economic losses (Yan et al., 2009; Dai et al., 2013). However, studies attempting to explain the annual general patterns of phytoplankton succession in these ponds are few, and the main factors driving the succession are poorly understood. In this backdrop, this study was undertaken with the aim of documenting the community dynamics of phytoplankton in relation to environmental factors in mussel-fish integrated ecosystem. 


\section{Materials and methods}

Study area

A mussel-fish integrated pond (area - $64 \mathrm{~m}^{2}$; annual average water depth - $1.6 \mathrm{~m}$ ) situated in Deqing Pearl Farm $\left(30^{\circ} 43.90^{\prime} \mathrm{N} ; 120^{\circ} 18.73^{\prime} \mathrm{E}\right)$ was selected for this study. Lime $(\mathrm{CaO})$ was applied in June and July@60 g m² each month. Organic manure was applied intermitantly in order to provide natural food. The pond was stocked with 4 year old mussels, $H$. cumingii along with Mylopharyngodon piceus $(2.07 \pm 0.62 \mathrm{~g}), C$. idella $(33.48 \pm 2.85 \mathrm{~g})$ and H. molitrix (13.52 $\pm 4.87 \mathrm{~g})$ at a stocking ratio of 5:10:3:1. The stocking density of $H$. cumingii was 1.0 indviduals $\mathrm{m}^{-3}$. Formulated feed was regularly supplied every morning with an average annual feeding of $12 \mathrm{~kg} \mathrm{~m}^{-2}$.

\section{Sampling and analysis}

Surface water and phytoplankton samples were collected between 9.00 and $10.00 \mathrm{hrs}$ once in a month from December 2012 to November 2013. Sampling, analyses, as well as the recording of 12 environmental variables, comprising water temperature (WT), water depth (WD), $\mathrm{pH}$, dissolved oxygen (DO), chemical oxygen demand (COD), chlorophyll a (Chl a), transparency, total nitrogen (TN), total phosphorus (TP), ammonia nitrogen $\left(\mathrm{NH}_{3}-\mathrm{N}\right)$ and nitrite nitrogen $\left(\mathrm{NO}_{2}-\mathrm{N}\right)$ were carried out following the standard method of Lv et al. (2014). Calcium ion $\left(\mathrm{Ca}^{2+}\right)$ was estimated by titrimetric method. All measurements were done in triplicates.

Phytoplankton biovolume was estimated by multiplying each species density by the mean volume $\left(\mu \mathrm{m}^{3}\right.$ unit $\left.^{-1}\right)$ based on standard geometric formulae (Hillebrand et al., 1999). Biovolume values were then converted to fresh biomass assuming $1 \mu^{3}$ equals $1 \mathrm{pg}$ (Eker and Kideys, 2003). Phytoplankton functional groups were identified following the keys of Reynolds et al. (2002) and Padisak et al. (2009). Few species that were hard to assign to taxa based on literature, were classified to unknown taxon. Those contributing more than $5 \%$ of the total biotic data were classified as prevailing functional groups. Sampling times were used to represent the temporal factors.

Trophic state assessment

The trophic state was assessed using the comprehensive nutritive index TSIc, which is calculated according to the formula of Cai (1997) based on the classical Carlson TSI (Carlson, 1977). The scale values of TSIc ranks on a numerical scale of 0 to 100 , which correspond with different trophic state conditions (Table 1) (Yang et al., 2012; Lv et al., 2014).

\section{Data analysis}

Exploratory, correlation, cluster and ordination analyses were performed using the R 3.0 software
Table 1. Evaluation standard for trophic state based on TSIc

\begin{tabular}{ll}
\hline Scale value of TSIc & Trophic state condition \\
\hline $0<\mathrm{TSI} \leq 30$ & Oligotrophic \\
$30<\mathrm{TSI} \leq 40$ & Oligo-mesotrophic \\
$40<\mathrm{TSI} \leq 50$ & Mesotrophic \\
$50<\mathrm{TSI} \leq 60$ & Light eutrophic \\
$60<\mathrm{TSI} \leq 70$ & Middle eutrophic \\
$70<\mathrm{TSI} \leq 100$ & Hypereutrophic \\
\hline
\end{tabular}

(R Development Core Team, 2010). Ward method based on Bray-Curtis distances for cluster analysis was chosen to categorise temporal samples. For canonical ordination, all environmental factors as well as prevailing functional groups or species contributing $\geq 1 \%$ to the biotic data at least once were used. Initially, detrended correspondence analysis (DCA) for the biotic data was employed to decide whether linear or unimodal ordination methods should be applied. Prior to the DCA analysis, raw biotic data were Hellinger transformed (Legendre and Gallagher, 2001) while environmental data were log transformed $[\log 1 \mathrm{p}(\mathrm{x})]$. The DCA results revealed that the longest gradient lengths were shorter than 3.0, indicating that the majority of species or functional groups exhibited linear responses to environmental variation. Redundancy analysis (RDA) was chosen to examine variations in the community structure. Ability of the environmental variables to explain the variance in biotic data in RDA was tested using Monte Carlo simulation with 999 permutations. Variables were considered to be significant when $\mathrm{p}<0.05$.

\section{Results and discussion}

Composition and succession of phytoplankton in
taxonomic groups

In total, 72 taxa of phytoplankton were identified, belonging to eight phyla (i.e., Bacillariophyta, Chlorophyta, Cyanophyta, Chrysophyta, Cryptophyta, Euglenophyta, Pyrrophyta and Xanthophyta). The most diverse groups were Chlorophyta (37 species, accounting for $51.4 \%$ of total), followed by Bacillariophyta (14 species, accounting for $19.4 \%$ of total) and Cyanophyta (11 species, accounting for $15.3 \%$ of total). The density of phytoplankton ranged

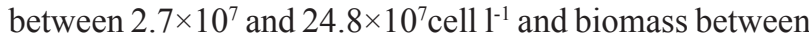
22.7 and $260.9 \mathrm{mg} \mathrm{l}^{-1}$ (Fig. 1a, b). Clearly, the density and biomass of Cyanophyta were greater during the high temperature period from May to November than the low temperature period from December to April. Meanwhile, Bacillariophyta showed relatively high density and biomass during the low-temperature period. Overall, the dominant assemblages were Chlorophyta, Cryptophyta, Cyanophyta and Bacillariophyta in terms of their density and biomass.

Since Sommer et al. (1986) defined the succession pattern in plankton in the Plankton Ecology Group (PEG) 


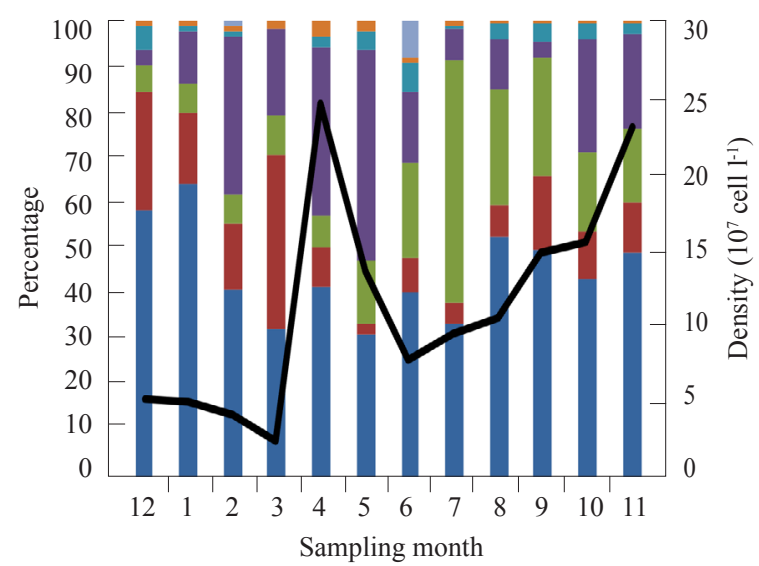

(a)

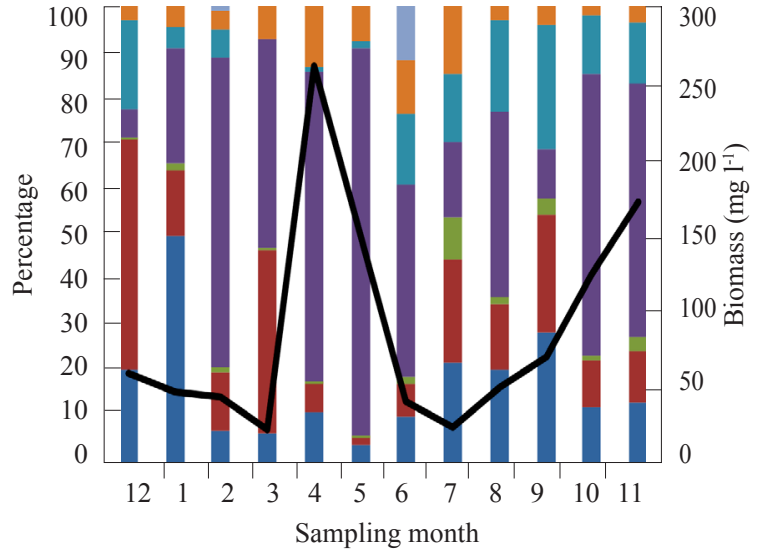

(b)

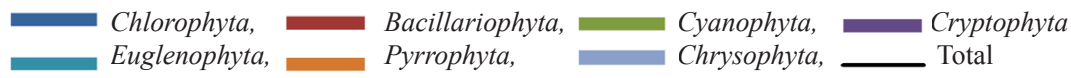

Fig. 1. Phytoplankton community succession of major taxonomic groups based on (a) density data, (b) biomass data

mode, the seasonal succession of phytoplankton has been described from numerous studies in various water bodies, such as lakes, reservoirs and ponds (Takamura et al., 1995; Lv et al., 2014; Masmoudi et al., 2015). There were distinct seasonal shift in phytoplankton communities based on density data of eight taxonomic groups (Fig. 1a). Cyanobacteria prefer higher temperature, and sustained high growth rates from April to November, and dominated the community in July. As surface water temperature and nutrients (TN, TP) concentration decreases, the appearance of Bacillariophyta species (Melosira granulate, Navicula sp., Cyclotella sp.) were able to sustain high organismic growth rates and became the dominant group in March, accounting for 38.1\% of the total density. However, adaptable Cryptophyta, especially species of Cryptomonas proliferated rapidly and achieved dominant position in January, April and May, accounting for $34.5,36.6$ and $46.1 \%$ of the total density, respectively. This change indicated Cryptophyta species were not strictly restricted by temperature. However, seasonal succession pattern based on biomass was not so obvious. Cryptophyta formed dominant assemblages during most of the months (Fig. 1b). Cluster analysis indicated

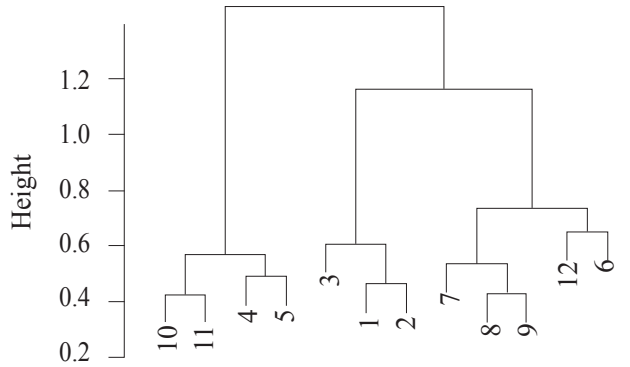

(a) that both density and biomass of samples were clearly divided into two clusters at height of 1.2 (moderate and extreme-temperature clusters) (Fig. 2a,b). One cluster is comprised of samples with temperature ranging from $18-25^{\circ} \mathrm{C}$, while the other one lower than $10^{\circ} \mathrm{C}$ or around $30^{\circ} \mathrm{C}$.

Composition and dynamics of phytoplankton in functional groups

Phytoplankton were divided into 23 groups viz., B, C, D, E, P, F, G, M, H1, J, L $, \mathrm{L}_{\mathrm{M}}, \mathrm{MP}, \mathrm{N}_{\mathrm{A}}, \mathrm{S} 1, \mathrm{~W} 1, \mathrm{~W} 2$, $\mathrm{X} 1, \mathrm{X} 2, \mathrm{X} 3, \mathrm{Y}, \mathrm{T}_{\mathrm{C}}, \mathrm{T}_{\mathrm{D}}$ and unknown functional groups based on the morphological and ecological characteristics as per the trait-separated functional groups described by Reynolds et al. (2002) and Padisak et al. (2009). The most frequently occurring groups were $\mathrm{P}, \mathrm{X} 1, \mathrm{X} 2, \mathrm{~J}, \mathrm{Y}$ and $\mathrm{L}_{\mathrm{O}}$ (accounting for $100 \%$ occurrence), followed by MP and $\mathrm{M}\left(91.7 \%\right.$ respectively), and $\mathrm{N}_{\mathrm{A}}(83.3 \%)$. Prevailing groups were $\mathrm{P}, \mathrm{X} 1, \mathrm{X} 2, \mathrm{~J}, \mathrm{M}, \mathrm{N}_{\mathrm{A}}$, Lo, Y, MP, S1 and $\mathrm{E}$ based on density, while P, X2, MP, Lo, Y, W1 and E based on biomass. The composition of the phytoplankton community and pattern of succession were analysed using these prevailing functional groups. In terms of

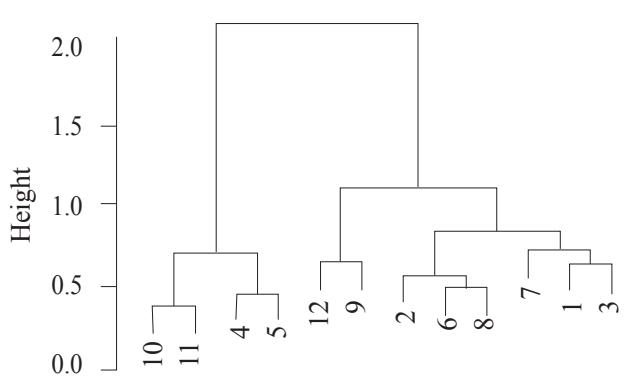

(b)

Fig. 2. Ward cluster dendrogram of phytoplankton community at taxonomic level based on (a) density data, (b) biomass data 
density, Bacillariophyta groups $\mathrm{P}$ (Melosira granulate and Fragilaria capucina) accompanied by one of three functional groups (Chlorophyta group J, Chlorophyta group X1, Cryptophyta group Y) were abundant from December to March. Group Y (Cryptomonas erosa, C. rostrata and C. Ovata) was dominant during two periods (from April to May and from October to November) and group Lo (Snowella lacustris and Merismopedia tenuissima) from June to September (Fig. 3a). However, no distinct temporal biomass shifts at functional levels were found (Fig. 3b). Cryptophyta group Y was typically dominant during most of the months. Cluster analysis indicated clear division into two clusters (low and high temperature clusters) based on density data at height of 1.0 (Fig. 4a). However, clusters divided by biomass data showed a similar structure as indicated by phytoplankton community of taxonomic groups (Fig. 4b).

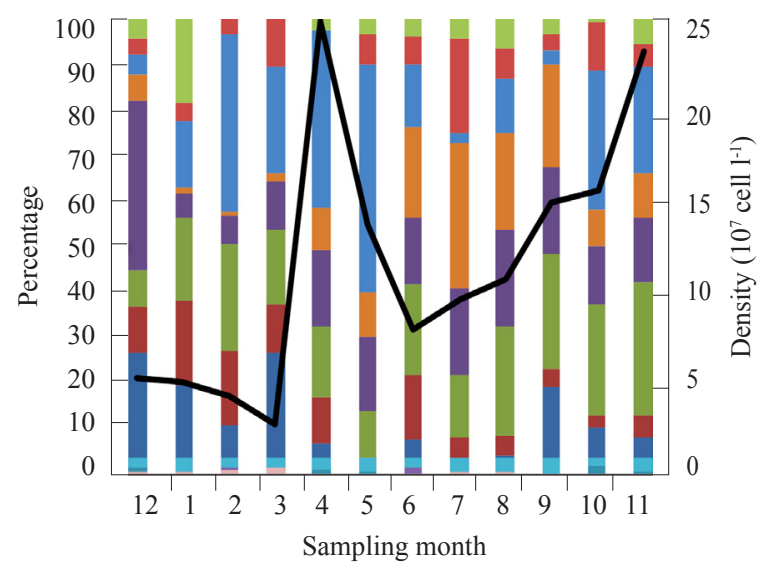

(a)

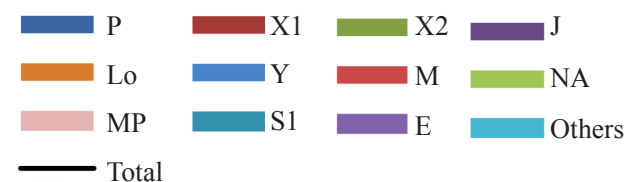

Environmental parameters and trophic state assessment

$\mathrm{NO}_{2}-\mathrm{N}, \mathrm{TP}, \mathrm{Ca}^{2+}$, transparency and WT showed significant differences between months. Chl a showed significant negative association with transparency $(p<0.01)$, and significant positive correlation with TP and WT $(p<0.05)$. TN:TP mass ratios were significantly related with $\mathrm{TP}$ and $\mathrm{NO}_{2}-\mathrm{N}$ at $\mathrm{p}<0.05$ and $\mathrm{p}<0.01$, respectively. TN:TP mass ratio were relatively high during low temperature period $\left(5-7^{\circ} \mathrm{C}\right)$ and November, with values lower than 68 in other months, indicating the pond was generally $\mathrm{N}$-limited during high-temperature period $\left(18-33^{\circ} \mathrm{C}\right)$ or P-limited during low-temperature period.

The comprehensive nutritive index TSIc is widely used in trophic state assessment (Lv et al., 2014). The TSIc values ranged between 61.5 to 79.0 , specifically indicating a middle mesotrophic state condition from December to May which coincides with low temperature $\left(5-7^{\circ} \mathrm{C}\right)$,

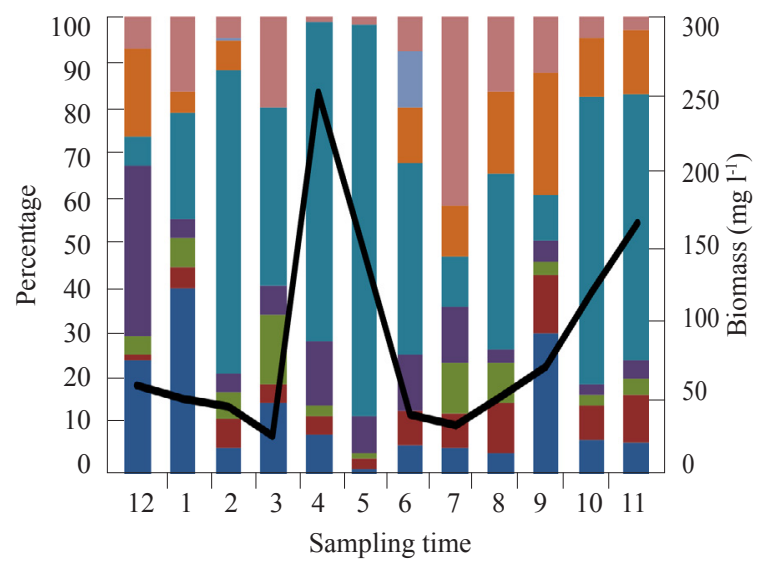

(b)

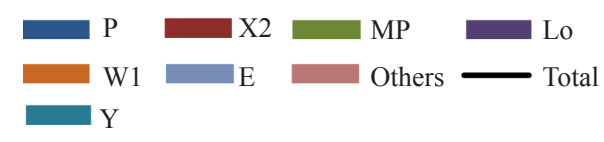

Fig. 3. Phytoplankton community succession of major functional groups based on (a) density data, (b) biomass data

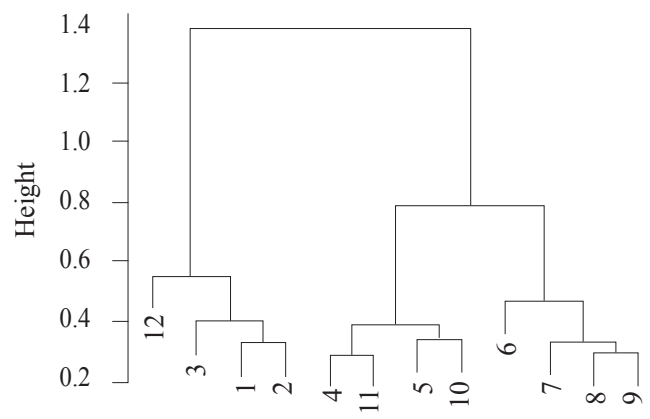

(a)

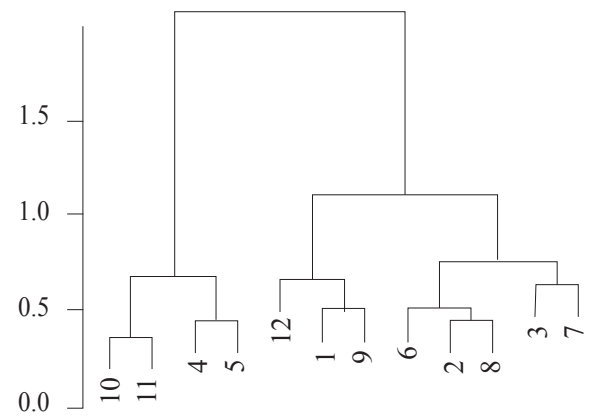

(b)

Fig. 4. Ward cluster dendrogram of phytoplankton community at functional level based on (a) biomass data, (b) biomass data 
a hypereutrophic condition in the remaining months having high temperature $\left(18-33^{\circ} \mathrm{C}\right)$. This conclusion was generally consistent with reports from waters culturing freshwater pearl mussels (Zhu et al., 2008).

In artificially controlled breeding ponds, species related to nutrient sufficiency and good light conditions were able to sustain high appearance rates with the input of exogenous nutrients during the breeding process (Calijuri et al., 2002). In this pond, such groups were Chlorella sp., Chlamydomonas sp., Ankistrodesmus falcatus, Chroomonas acuta and Peridinium sp., which belongs to groups X1, $\mathrm{X} 2$ and Lo. The $100 \%$ occurrence frequencies of these functional groups in turn indicated eutrophic condition of the water. High density of Chlorophyta indicated organic polluted and eutrophicated condition of water ( $\mathrm{Lu}$ et al., 2010). Blooms of Cryptophyta in January, April and May accompanied by decrease and even disappearance of Chrysophyta also verified the organic pollution (OrtegaMayagoitia et al., 2003). Therefore, it was deduced that our experimental pond was in a eutrophic and organic

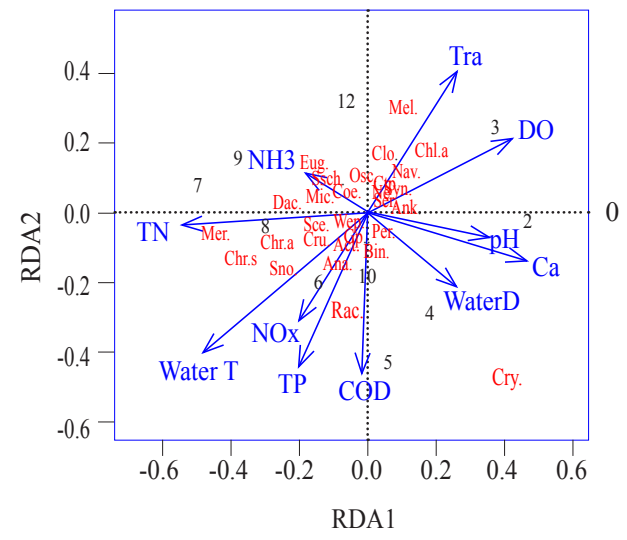

(a) polluted state with comprehensive consideration of TSIc and advantageous phytoplankton assemblages.

Relationship between phytoplankton community and environmental factors

Factors that are necessary for the growth of phytoplankton, such as nutrition, light, biological effects (predation, parasitism), may become limiting factors to the succession of phytoplankton community (Kagami et al., 2007; Xiao et al., 2011). Studies have confirmed that changes in nutrient concentrations have a greater effect on the phytoplankton community than climatic factors such as temperature (Salmaso, 2010; Dong et al., 2012). In the present study, Monte Carlo simulation revealed that water temperature was the most important variable to influence the density-based community of phytoplankton (Fig. 5a), which was consistent with the view of Jin et al. (2012). TN played the most important role in shaping the biomass-based community (Fig. 5b). Details of abbreviations of taxonomic groups in the two figures, are presented in Table 2.

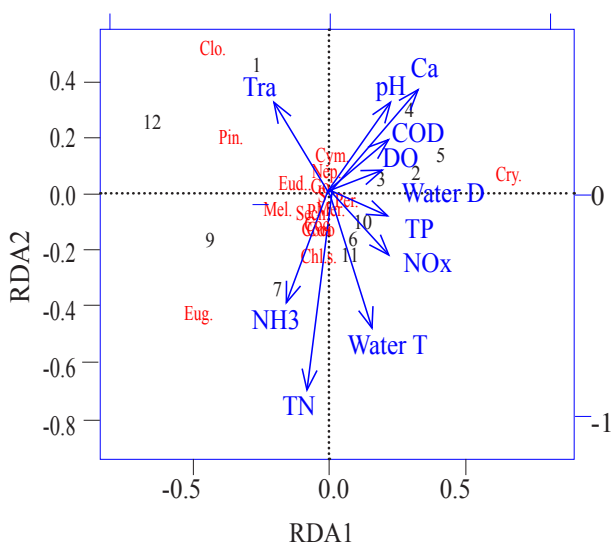

(b)

Fig. 5. RDA ordination showing phytoplankton community composition (a) density based, (b) biomass based

Table 2. Abbreviations of taxonomic groups in RDA ordination analysis

\begin{tabular}{llllll}
\hline Abbreviation & Group & Abbreviation & Group & Abbreviation & Group \\
\hline Clo. & Closterium & Act. & Actinastrum & Mer. & Merismopedia \\
Sta. & Staurastrum & Pla. & Planctonema & Osc. & Oscillatoria \\
Sce. & Scenedesmus & Glo. & Gloeotaenium & Aph. & Aphanizomenon \\
Chl-a. & Chlorella & Wes. & Westella & Sno. & Snowella \\
Chl-s. & Chlamydomonas & Nav. & Navicula & Dac. & Dactylococcopsis \\
Sch. & Schroederia & Mel. & Melosira & Ana. & Anabaena \\
Nep. & Nephrocytium & Cyc. & Cyclotella & Cry. & Cryptomons \\
Ped. & Pediastrum & Cym. & Cymbella & Chr-a. & Chroomonas \\
Cho. & Chodatella & Pin. & Pinnularis & Eug. & Ruglena \\
Ank. & Ankistrodesmus & Syn. & Synedra & Rac. & Phachomas \\
Tet-a. & Tetrachlorella & Gom. & Gomphonema & Pha. & Peridinium \\
Eud. & Eudorina & Ast. & Asterionella & Per. & Dinobryon \\
Cru. & Crucigenia & Fra. & Fragilaria & Din. & \\
Sel. & Selenastrum & Mic. & Microcystis & & \\
Coe. & Coelastrum & Chr-s. & Chroococcus & & \\
\hline
\end{tabular}




\section{Cyanobacterial dominance in ponds}

Cyanophyta (species of Microcystis, Aphanizomenon and Oscillatoria) were the most dominant groups in the mussel-fish integrated pond during high temperature period in terms of their density and biomass. Cyanobacteria blooming has become an obstacle to the sustainable development of pearl industry because of their toxicity (Havens et al., 2003). Cyanophyta mostly benefit from human influence through the combination of rising temperatures and increase in nutrients loading. The concentration and proportion of nutrients $(\mathrm{N}, \mathrm{P})$ in ponds for pearl production depend largely on stocking and management models (Wang et al., 2009). Though the favoured integrated stocking model was demonstrated to effectively improve the water quality and control excess growth of harmful phytoplankton, our study still found the occurrence of cyanobacterial blooming in July. Inappropriate management model, such as irregular fertilisation might be the main cause. According to the findings of Terziyski (2007), Jin et al. (2013) and Mischke (2014), fertilisation with organic or inorganic manure did not significantly influence the composition of species but increased their density. Fertilisation is a very common arrangement in order to sustain the quantity of phytoplankton needed for filter feeders. However, inappropriate fertilisation may greatly increase the risk of eutrophication and cyanobacterial blooming. Such worries have aroused increased attentions towards improving stocking and management models of freshwater mussels in order to maintain the water quality and restore the ecosystem of culture ponds.

\section{Acknowledgements}

This work was supported by Specialised Research Fund for the Doctoral Program of Higher Education (SRFDP) (no. 20123305110001); Zhejiang Science and Technology Project (2012C12907-5); Huzhou Municipal Natural Science Foundation (2014YZ06).

\section{References}

Cai, Q. H. 1997. On the comprehensive evaluation methods for lake eutrophication. J. Limnol. Sci., 9(1): 89-94. (in Chinese)

Calijuri, M. C., Dos Santos, A. C. A. and Jati, S. 2002. Temporal changes in the phytoplankton community structure in a tropical and eutrophic reservoir (Barra Bonita, S. P. Brazil). J. Plankton Res., 24: 617-634.

Carlson, R. E. 1977. A trophic state index for lakes. Limnol. Oceanogr., 22(2): 361-369.

Dai, Y. X., Wang, Y., Tang, J. Y. and Li, Y. M. 2013. Effects of co-cultured fish and feed supplement on water chemistry characteristics of freshwater pearl mussel farming. J. Fish. Sci. China, 20(2): 351-360.
Dong, J., Li, Y. H. , Li, G. B., Li, Y. D., Liu, Y. D. and Song, L. R. 2013. Seasonal dynamics characteristics and affecting physical factors of phytoplankton functional groups in Dongjiang River. Acta Hydrobiol. Sin., 37(5): 836-843.

Eker, E. and Kideys, A. E. 2003. Distribution of phytoplankton in the southern Black Sea in summer 1996, spring and autumn 1998. J. Mar. Syst., 39(3-4): 203-211.

Finlay, B. J. and Esteban, G. F. 1998. Freshwater protozoa: biodiversity and ecological function. Biodivers. Conserv., 7: 1163-1186.

Havens, K. E., James, R. T., East, T. L. and Smith, V. H. 2003. $\mathrm{N}$ : P ratios, light limitation, and cyanobacterial dominance in a subtropical lake impacted by non-point source nutrient pollution. Environ. Pollut., 122(3): 379-390.

Hillebrand, H., Durselen, C. D., Kirschtel, D., Pollingher, U. and Zohary, T. 1999. Biovolume calculation for pelagic and benthic microalgae. J. Phycol., 35(2): 403-424.

Jin, F. F., Sheng, J. Q., Hong, Y. J., Tao, R., Wang, S. H., $\mathrm{Wu}, \mathrm{X}$. M. and Lin, G. 2013. Difference between the composition and abundance of phytoplankton among four seasons with spreading different kind of manure in Hyriopsis schlegeli breeding ponds. J. Nanchang Univ. Nat. Sci., 37: 88-92.

Kagami, M., Bruin, A., Ibelings, B. W. and Donk, E. V. 2007. Parasitic chytrids: their effects on phytoplankton communities and food-web dynamics. Hydrobiologia, 578: 113-129.

Legendre, P. and Gallagher, E. D.2001. Ecologically meaningful transformations for ordination of species data. Oecologia, 129: 271-280.

Lu, N., Yin, H. B., Deng, J. Y., Gao, F., Hu, W. P and Gao, J. F. 2010. Spring community structure of phytoplankton from Lake Chaohu and its relationship to environmental factors. J. Lake Sci., 22: 950-956.

Lv, H., Yang, J., Liu, L., Yu, X., Zheng, Y. and Chiang, P. 2014. Temperature and nutrients are significant drivers of seasonal shift in phytoplankton community from a drinking water reservoir, subtropical China. Environ. Sci. Pollut. Res., 21: 5917-5928.

Masmoudi, S., Tastard, E., Guermazi, W., Caruso, A., MorantManceau, A. and Ayadi, H. 2015. Salinity gradient and nutrients as major structuring factors of the phytoplankton communities in salt marshes. Aquat. Ecol., 49: 1-19.

Mischke, C. C. 2014. Winter pond fertilization can increase phytoplankton density in aquaculture ponds. N. Am. J. Aquacult., 76: 67-71.

Ortega-Mayagoitia, E., Rojo, C. and Rodrigo, M. A. 2003. Controlling factors of phytoplankton assemblages in wetlands: an experimental approach. Hydrobiologia, 502: 177-186.

Padisk, J., Crossetti, L. O. and Naselli-Flores, L. 2009. Use and misuse in the application of the phytoplankton 
functional classification: a critical review with updates. Hydrobiologia, 621: 1-19.

R Development Core Team 2010. R: a language and environment for statistical computing. R Foundation for Statistical Computing, Vienna, Austria. http://www.R-project.org.

Reynolds, C. S., Huszar, V., Kruk, C., Naselli-Flores, L. and Melo, S. 2002. Towards a functional classification of the freshwater phytoplankton. J. Plankton Res., 24: 417-428.

Salmaso, N. 2010. Long-term phytoplankton community changes in a deep subalpine lake: responses to nutrient availability and climatic fluctuations. Freshw. Biol., 55: 825-846.

Sommer, U., Gliwicz, Z. M., Lampert, W. and Duncan, A. 1986. The PEG-mode of seasonal succession of planktonic events in fresh-waters. Arch. Hydrobiol., 106: 433-471.

Takamura, N., Zhu, X. B., Yang, H. Q., Jiang, X. Y., Li, J. L., Mei, Z. P., Shi, Z. F. and Tan, Y. J. 1995. Characteristics of plankton communities in Chinese integrated fish ponds: effects of excessive grazing by planktivorous carps on plankton communities. Hydrobiologia, 315(3): 211-225.

Terziyski, D., Grozev, G., Kalchev, R. and Stoeva, A. 2007. Effect of organic fertilizer on plankton primary productivity in fish ponds. Aquacult. Int., 15: 181-190.

Tucker, C. S. and Lloyd, S. W. 1984. Phytoplankton communities in channel catfish ponds. Hydrobiologia, 112: 137-141.

Wang, Y., Xie, N. X., Lin, Q. X. and Gao, J. H. 2009. Water quality, growth and pearl production of freshwater pearl mussel, Hyriopsis cumingii in commercial ponds located in Zhuji. Freshw. Fish., 39: 68-72.

Xiao, L. J., Wang, T., Hu, R., Han, B. P., Wang, S., Qian, X. and Padisak, J. 2011. Succession of phytoplankton functional groups regulated by monsoonal hydrology in a large canyon-shaped reservoir. Water Res., 45: 5099-5109.

Xu, H. L., Song, W. B., Warren, A., Al-Rasheid, K. A. S, Al-Farraj, S. A., Gong, J. and Hu, X. Z. 2008. Planktonic protist communities in a semi-enclosed mariculture pond: structural variation and correlation with environmental conditions. J. Mar. Biol. Assoc. UK, 88: 1353-1362.

Yan, L. L., Zhang, G. F., Liu, Q. G. and Li, J. L. 2009. Optimization of culturing the freshwater pearl mussels, Hyriopsis cumingii with filter feeding Chinese carps (bighead carp and silver carp) by orthogonal array design . Aquaculture, 292: 60-66.

Yang, J., Yu, X. Q., Liu, L. M., Zhang, W. J. and Guo, P. Y. 2012. Algae community and trophic state of subtropical reservoirs in south-east Fujian, China. Environ. Sci. Pollut. Res., 19: 1432-1442.

Zhu, S. B., Wang, Y., Wang, X. D., Wang, W. L. and Dong, X. Q. 2008. Plankton community and primary productivity in waters for culturing freshwater pearl mussel (Hyriopsis cumingii) under different stockings and management models. Chinese J. Ecol., 27: 401-407. 